\title{
Risk Allocation and Mitigation in Nigeria's Privatisation Programme-A Case Study of Electric Power Sector Privatisation
}

\author{
George Nwangwu ${ }^{1,2}$ \\ ${ }^{1}$ Research Fellow, African Procurement Law Unit, Department of Mercantile Law, Stellenbosch University, South Africa \\ ${ }^{2}$ Honorary Senior Research Associate, The Bartlett School of Construction \& Project Management, University College London, \\ London, UK \\ Email: gnwangwu@gmail.com
}

How to cite this paper: Nwangwu, G. (2021) Risk Allocation and Mitigation in Nigeria's Privatisation Programme-A Case Study of Electric Power Sector Privatisation. Journal of Power and Energy Engineering, 9, 1-17. https://doi.org/10.4236/jpee.2021.98001

Received: April 6, 2021

Accepted: August 9, 2021

Published: August 12, 2021

Copyright $\odot 2021$ by author(s) and Scientific Research Publishing Inc. This work is licensed under the Creative Commons Attribution International License (CC BY 4.0).

http://creativecommons.org/licenses/by/4.0/

\begin{abstract}
Under the Nigerian privatisation programme, the issues of risk allocation and mitigation were never always properly handled. Historically, there had always been a tendency to dump all the project risks on the private sector partner without properly evaluating whether it was capable of managing them. Extant literature has shown that where the comparative advantages of parties to handle risks are not properly taken into consideration, the allocation of risk is unbalanced and the tendency for the project to run into difficulties and/or fail increases. This paper looks at the electric power sector privatisation, distilling how key project risks were handled under the exercise. This should be a good pointer as to whether the privatisation exercise would be a success in the long run.
\end{abstract}

\section{Keywords}

Risk Allocation, Risk Mitigation, Electric Power Sector, Privatisation, Nigeria

\section{Introduction}

For over three decades Nigeria embarked on a very ambitious privatisation programme which has witnessed the divestiture of over 200 hitherto publicly owned assets to the private sector [1]. This programme has covered nearly all aspects of the Nigerian economy including banking, transportation, mining, manufacturing and oil and gas sectors. In 2013, the country also privatised a number of power sector assets, which included 11 distribution companies and 7 generation companies. The method of divestiture under the privatisation programme in- 
cluded asset sales, share sales, commercialisations and concessions [2].

It is important at this juncture to make a clear distinction between privatisation, concessions and other forms of Public Private Partnerships (PPPs). Whilst in the strict sense, privatisation involves the complete divestiture of assets by the government to private sector investors, under PPPs the government typically has a reversionary interest in the assets. This distinction is important since if we rely on the definition of privatisation above, the transfer of risk to the private sector should be absolute as it is synonymous more or less with an asset sale. However, the privatisation programme in Nigeria also involved some forms of PPPs, like concessions in which the government enjoys a reversionary interest in the asset at the end of the concession period. PPPs by their nature require a more delicate balancing of risks between the private and public parties. It is within this broader context that the electric power sector privatisation should be viewed.

Historically, under the Nigerian privatisation programme, scant attention was paid to the proper management of risks [3]. Instead, there had always been a tendency to dump all the project risks on the private sector partner without properly evaluating whether it was capable of managing them. The practice of dumping risks on the private sector appeared favoured by the public sector because the primary concern of the Nigerian government was always to raise money outside of its own balance sheet. Invariably, the consideration of the other benefits that arise from private sector led finance for infrastructure have been secondary. The flawed philosophical underpinnings and the rather dubious political message around privatisation and PPPs in Nigeria has always been that all the financial burden and operational responsibility for the privatised assets rested with the private sector and the public sector only enjoyed the resultant benefits (This is clear from the different policy pronouncements of government). Extant literature has however shown that where the comparative advantages of parties to handle risks are not properly taken into consideration, the allocation of risk is unbalanced and the tendency for the project to run into difficulties and/or fail increases [4]. This is one of the major reasons why a number of the privatized enterprises and nascent PPP projects are under performing [3].

However, the trend discussed in the previous paragraph seems to be changing and recently, there appears to be a conscious effort to evaluate and manage project risks better. It is against this background that this paper evaluates the improved risk allocation and mitigation framework that was deployed under the privatisation programme using the privatisation of the electric power assets as a case study.

\section{Literature Review}

A risk is defined as any factor, event or influence that could threaten the successful completion of a project in terms of time, cost or quality [5] [6]. It is said to be characterised by a number of components: The risk event; what might happen to the detriment or in favour of the project, the probability of occurrence; the chance of the event occurring and the potential loss or gain; conse- 
quence of the event happening [7]. However, the best way to view risk is not just as a threat with negative consequences but also as having positive effects since it also provides opportunities for the parties to the project to innovate. For this reason, the definition by Al-Bahar, that risk is the exposure or chance of occurrence of events adversely or favorably affecting project objectives as a consequence of uncertainty, is preferred [8].

The central concern in every project, whether carried out through traditional procurement, privatisations or PPPs remains whether the project will be profitable taking into consideration all the risks that are inherent in it [9]. The management of risk is fundamental to the success of projects. In fact, it has been suggested that the main purpose of project management is to manage the risks in a project [10]. Nonetheless, while risk has always played an important role in project management, awareness of risk has increased greatly under privatisations and PPPs due to the fact that there is a continued long term relationship between the private and public sector parties after the underlying assets have been transferred. Indeed, the centrality of risk to privatisations and PPPs has raised the awareness of project risks to the level which public procurement has not been able to do to date [11]. The management of risk involves:

1) Risk identification: the process of identifying all the risks relevant to the project;

2) Risk assessment: the determination of the degree of likelihood of the risk and the possible consequences if the risk occurs;

3) Risk allocation: assignment of the responsibility of the consequence of the risk to one or more of the contracting parties;

4) Risk mitigation: the process of controlling the likelihood of occurrence of the risk and or the consequence of the risk [4].

A review of extant literature reveals that there has been an extensive body of work on risk management. This is in concurrence with the position of Taroun, who found that risk management has been one of the key topics in project management publications in recent times [11]. According to Pellegrino et al., risk management is not static but dynamic, corresponding to the evolution of risk overtime [12]. The authors therefore proposed a real options theory for risk management that takes into consideration the managers choice to react proactively to uncertainties. The manager's flexibility can be considered as a real option [12]. Zou, Patrick X.W et al. developed a lifecycle risk management framework for PPP infrastructure projects. According to the authors, this will lead to the realization of VFM and balance of interests between the different partners [13]. Fischer $\mathrm{K}$ et al. propose an integrated risk management system for PPP projects. According to them, this will induce transparency by utilizing better sources of data and information distribution [14]. Xiong suggests that ex ante risk management is no longer sufficient to deal with the high occurrence of renegotiations and early terminations of PPP projects. The author proposes an ex-post risk management model which will facilitate government's decision making in PPP projects [15]. This paper further utilizes some of the risk man- 
agement frameworks. Specifically, the paper adopts the ex-post risk management model proposed Xiong to conduct a post-mortem on the Nigerian electric power privatisation [15].

There is no agreement on the exact nature and number of risks that a project may face. The reason is simply because risks vary from project to project and even within the lifespan of the same project, is likely to change from time to time. More so, many of the so-called categories of risks overlap with one another. In summary however, risk factors may be categorized from different perspectives, some from more general perspectives and others from more precise formulations. There is also a lack of uniformity in the use of semantics in making the classifications resulting in the use of different labels for the same type of risks by different scholars. Nevertheless, there are diverse classifications of risk factors in projects. It is important to note that risk classification is mostly predicated on perception of risk and that the perception of risk itself is determined principally by social and economic factors. Therefore, despite the fact that a number of project risks were considered prominent during the privatisation programme, only a few have been analysed in this paper. This is for pragmatic reasons as it enables a thorough evaluation of particular risks that were more relevant in the project than if a more generalist approach was taken. The risks that are discussed below are political risk, demand risk, exchange rate risk and force majeure risk.

\section{Design, Methodology and Approach}

The principal methodology used in carrying out this research is the case study methodology. A case study is an empirical methodology that investigates a contemporary phenomenon within its real life context using multiple sources of evidence [16]. It is suitable for answering the questions about "how" and "why" things happen, when you can't manipulate the behaviour of those involved in the study, when the boundaries are not clear between the phenomena and the context and allows investigations into contextual realities [17]. Case studies also allow investigations into the differences between what was planned and what actually occurred [18]. It is said to be appropriate, just like in the present study, where one needs to understand some particular problems or situations in greater depth and where one can identify cases rich in information [19] [20]. It is also useful for testing hypothesis [21].

The approach adopted in this paper is based on a literature analysis, aimed at identifying key risks and related best practice mitigation strategies. The risk management strategies adopted in the Nigerian electric power privatisation were then compared with the identified risk mitigation strategies to ascertain any shortcomings. The data that was used for the case study was obtained from several sources. Firstly, documentary evidence was the most used source of information. Some of the documents used were transaction documents like the Request for Proposals and project contracts. Others were parliamentary reports 
and proceedings. The second source of data was media reports including newspapers, magazines and other commentaries from other researchers, while stakeholder interviews formed the third source of data. The use of these multiple sources of data for triangulation helped validate and enhance the reliability of the findings. This is in consonance with the suggestion by Yin, who advocates for this method on the basis of the ethical need to confirm the validity of the data and process [16].

The findings from this research should be of practical use to project stakeholders which include policy makers, project developers and PPP professionals in Nigeria and across the developing world. This is because the study throws more light on how to manage risks associated with privatisation PPP projects and therefore helps parties avoid some of the pitfalls arising from lack of proper project risk management.

\section{Limitation of Study and Area for Future Research}

This study is limited to analysing how certain risks were managed under the Nigerian electricity privatisation. Since the conclusion of the electricity sector privatisation, there have been a number of assets and sectors that have also undergone privatisation. There is therefore a need to conduct additional case studies on some of the other sectors in which privatisation, has taken place in Nigeria (For instance the MMA 2 Airport project in Lagos). This will provide additional evidence to triangulate the findings of this paper on whether there has been an improvement on manner in which project risks are now being managed in Nigeria. For this reason, it is suggested that a viable area for further research would be conducting similar case studies on some of the other infrastructure sectors that have also been recently privatised.

\section{Political Risk}

Political risk is hard to define because it is a collection of a fluid number of occurrences. In summary, it can be said that the exercise of political power is the root cause of political risk [22]. Political risk is however a large amorphous category. It is said to contain virtually all "risks associated with business or investment in a country which would not be present in another country with a more stable and developed business and economic climate and regulatory regime" (The contention that political risk is more likely to eventuate in developing countries is true, however recent events have shown that political risk also exists in developed countries. This was obvious for instance from the outcome of the recent exit of Britain from the European Union) [23]. Some of the components of political risk are currency incontrovertibility and transfer restriction, expropriation, breach of contract, political violence, legal, regulatory and bureaucratic risks and non-governmental action risks. Investors will avoid countries where there are high incidences of these factors. This is why it is said that political risks have an impact on a country's development [24]. 
Bearing in mind that the major thrust of the Nigerian electric power sector reform programme was to accelerate the process of private sector participation in the sector, it was therefore important for government to show that private sector investments would be safe from political interference. In accordance with the general trend across the world, political risk was allocated to the government under the privatisation exercise. The Nigerian government managed this risk through the passage of a number of legislations, the most important of which was the Electric Power Sector Reform Act (EPSRA), which provided considerable safeguards for the private sector investors. In addition, government put in additional measures to provide assurances to investors employing a number of risks mitigating strategies to manage this risk. Below are some of the discernible strategies.

\subsection{Good Project Governance}

Good project governance is one of the most important strategies for managing political risk. Therefore, it is appropriate that the first place to start the discussion of the mitigation of political risk in the Nigerian power sector privatisation programme is the implementation of good project governance throughout the transaction process. According to the United Nations, good governance encompasses 6 core principles: a fair and transparent selection process; attainment of value for money; commitment to the improvement of public services; fairness to all parties; sensible dispute resolution mechanisms and the guaranteed safety of the investors, their investments and the project [25]. These principles were to a large extent respected throughout the privatisation process.

The assurance of good project practice was essential in order to give investors confidence to participate in the process. As can be gleaned from the core principles enumerated above, one of the bedrocks of a good project governance process is the employment of a transparent procurement process [26]. The government realised from the onset that a "fast-track arrangement" favouring a particular firm or bidder may lead to public suspicion of corruption and underhand deals. Apart from deterring prospective bidders, the toxic public opinion that this was likely to generate would have forced the hands of the government, especially succeeding governments, to nullify the deals in order to score political gains with the public. It was therefore essential that clear and unambiguous rules and regulations were put in place prior to the commencement of the procurement phase of the transactions. Such regulations were strictly adhered to in order to avoid undue benefits accruing to any particular entity. There was a two-stage bidding process, where a number of bidders were preselected and requested to respond to Request for Proposals (RFPs). The RFPs stipulated the bidding rules which were respected throughout the process. These rules were so strictly adhered to that a number of bidders who submitted their bids late were locked out of the transaction and this drew widespread commendation from several quarters (For instance, Dangote Industries (the biggest business in Nigeria) with all its economic and political clout was prevented from submitting a 
late bid).

\subsection{Partial Risk Guarantees/Political Risk Guarantees}

Due to the fear of the investors that the government may interfere with the procurement process and breach its contract with investors and in extreme cases even expropriate the assets, the Federal Government was encouraged from the onset of the privatisation process to procure the World Bank Partial Risk Guarantees (PRGs) also known as political risk guarantees to provide prospective investors with some level of comfort. This instrument typically covers losses arising from the breach of host government's contractual obligations to private sector investors. In summary, they cover risks such as expropriation, breach of contracts, sovereign debt default and currency transfer or controvertibly risk. PRGs have the advantage of upgrading the host government's credit rating and lowering financing costs of the project, because the premium placed on the guaranteed risk by the private sector when pricing the risk is considerably lower.

Most investors were disappointed when the PRGs were not provided as promised from the onset of the privatisation exercise. There were several meetings with the World Bank and even the African Development Bank without any success. Investments in the Nigerian power sector were however completed despite the non-availability of this risk mitigation instrument. In some cases, investors have been encouraged to obtain the instrument themselves and bear the costs if they so desire. This option has not however been taken up by investors. The reason for this may be due to some of the major shortcomings of PRGs, as they are too expensive and usually have limited coverage. For instance, they do not cover political violence and do not extend to all types of projects. It should however be noted that the subsequent greenfield Azura power project that came on stream after the conclusion of the privatisation exercise was granted a PRG by the government, once again showing that the sector is bedevilled with a lot of policy inconsistency.

In any case, it is suggested that risk mitigation instruments like PRGs are no panacea for all political risks; robust legislations play a better role. However, it is conceded that PRGs may help bridge the gap while a country establishes a sound legal and policy framework that will reduce the risk and even afterwards support efficient risk sharing [27]. The relative success of the privatisation programme despite the non-availability of the PRGs may be an indication that investors have found adequate comfort from the other risk mitigation instruments offered by government or in the alternative, that the investors might have priced the absence of PRGs into the offer prices made to government for the assets.

\subsection{Put and Call Option Agreements}

Another political risk mitigating instrument that was widely offered is the Put and Call Option Agreements (PCOA). The PCOA gives potential private sector partners comfort that if during the operational phase of the asset, the government fails to meet its obligations under the Power Purchase Agreement (PPA) 
and other supporting agreements, that the private investor may "put" the asset to the government which in turn is obliged to purchase the asset from the private sector party based on an agreed formula. The government may also exercise the option to "call" the asset, in which case it is obliged to adequately compensate the investor (The amount of compensation payable by the government depends on which of the parties was in breach of their obligations under the government. Prima facie, where the government is responsible, it is obliged to pay much more for the asset, with the reverse the case where the private sector is responsible).

The use of the PCOA is predicated on the principle that assets, like power plants, once built are sunk resources and therefore it would not be practicable for the investor to move it to another location in the event that the business is no longer feasible. It is believed that in such cases, it is better for the government to buy the asset from the private sector. This is also a politically astute policy since it is not seen as government granting the private sector subsidies, which is usually frowned against by taxpayers. Rather, the PCOA allows the government more policy flexibility to step in and save the asset in situations which would otherwise have led to depriving the citizens the use of essential services.

In practice, while the PCOA has been provided to some investors, a number of other investors have been denied this instrument. The willingness of the government to provide this incentive seems to be dependent on the negotiation skills of potential investors rather than a consistent policy of the government. This discretionary approach is flawed and will potentially lead to a lot of confusion in the sector. It is believed that the PCOA is a very good risk mitigation instrument that is beneficial to both the private sector and government and should therefore be applied consistently across all investors and assets.

\subsection{Direct Agreements}

During the privatisation process, one of the requests by the financiers that provided the funds for the private sector purchasers of the assets, was for the government to grant the financiers step in rights in the event that the private sector was unable to fulfil its obligations to them. These rights would allow the banks or other financial institution take over the asset and recover their investments in the event of default from their private sector borrowers. This was to be achieved through the entering into of direct agreements between the government and the banks. The direct agreements were a condition precedent demanded by the banks from their private sector customers before drawing down on the loans. After several meetings between the different parties, the government acceded to these requests. In essence, these direct agreements create a contractual nexus, which would otherwise never have arisen between the government and the financiers.

\subsection{Contractual Clauses}

Contractual clauses are good tools for mitigating political risk and this was skil- 
fully utilised during the negotiation process between government and the private sector investors. Some of the contractual clauses that were employed during the privatisation process for the management of political risk were: arbitration clauses, incorporation of Multilateral, Bilateral Investment Treaties and Free Trade Agreements, Sovereign Guarantees, Force Majeure clauses and Stabilization clauses.

\subsection{Arbitration Clauses}

Arbitration clauses were one of the commonly used contractual clauses that was employed in managing disputes whether arising from economic aspects of the contract or the political risks. This was not surprising as most investors prefer arbitration in neutral venues to settling disputes arising out of the occurrence of political risk events in the local courts. More potency was therefore added to the use of arbitration as the dispute settlement procedure by the use of a "favourable jurisdiction clause" and the use of a "favourable governing law clause", which suggested for instance the application of a neutral law and jurisdiction for the resolution of disputes between the parties. Parties during the privatisation process routinely chose English law and London as the governing law and the favoured place for arbitration respectively. Note however that the agreement to refer a dispute to arbitration is itself a contract that can be breached.

\subsection{Multilateral, Bilateral Investment Treaties and Free Trade Agreements}

According to the International Institute for Sustainable Development (IISD), there exists approximately 3000 investment treaties, including bilateral investment treaties, regional agreements and investment protection provisions in Free Trade Agreements [28]. Nigeria is a signatory to a number of these multilateral treaties. The typical clauses found in an investment treaty are; 1) Clauses providing for rules on indirect expropriation; 2) Clauses on fair and equitable treatment of foreign investors; 3 ) Clauses on the protection of investment agreements concluded between a foreign investor and a host country ("umbrella clauses") [29]. The major advantage of investment treaties and free trade agreements is that a private sector party who suffers or anticipates a violation of its contractual rights under the treaties may have recourse to arbitration through for instance the International Centre for the Settlement of Investment Disputes (ICSID) rather than subjecting itself to the courts of the host state. The uniqueness of these treaties is that even though they are entered into between states, private sector entities can enjoy the benefit of the treaties. Therefore, the fact that Nigeria is a signatory to ICSID and the fact that the contracts allowed for their incorporation into the transaction in particular was very helpful in giving investors, confidence to make investments. These treaties have however been criticised for their tendency to limit the sovereignty of host states and may result in reverse discrimination to the detriment of investors who are nationals of a host state as they contain only rights for foreign investors [30]. 


\subsection{Sovereign Government Guarantees}

It is customary for foreign investors in developing countries to demand for sovereign guarantees before making investments. The electric power privatisation in Nigeria was no different. Investors routinely demanded for guarantees during negotiations and this even extended to subsequent negotiations for the construction of greenfield power plants. The argument for sovereign guarantees is that it helps reduce the financial cost of the private sector because the government expressly assumes the risks mentioned in the guarantee instruments. However, guarantees have been criticized because it creates enormous and sometimes even unintended contingent liabilities for the government. It has been suggested that providing for impartial arbitration, regulatory independence and/or renegotiation can lower the probability that political guarantees will be called [30]. Note however, that these sorts of blanket guarantees were not widely provided in the privatisation of brownfield assets as the government insisted on appropriate transfer of commercial risks to the private sector. Their use in the electric power sector has been restricted to mostly greenfield transactions. Nevertheless, it is advised that governments should be especially careful in the use of guarantees because it may be dubiously used to bypass imposed fiscal constraints, due to its discretionary nature, undermine good governance and may lead to a guarantee culture where the private sector seeks guarantees as an alternative to properly managing project risks [30].

\section{Demand Risk}

Traditionally, demand risk in projects is usually allocated to private sector commercial operators since it is a commercial risk. However, as is customary in power projects, this risk was in this instance shared by the parties with the government taking most of the risk (This would have been different if the plant was built and operated on a merchant plant basis). The reason for this is that electric power is not capable of being stored and so is usually sold on a "take or pay" basis. The government employed a number of strategies discussed below to manage this risk.

\subsection{Creation of the Bulk Trader (NBET)}

It was obvious at the time that the nascent distribution companies were not viable enough to meet their financial commitments in the new electricity market. Since actual installed generation capacity was insufficient to generate sufficient cash flows and the collection rate (which was dependent on the reduction of Average Technical and Commercial Losses) was low and insufficient to fund the market, it was obvious to all market participants that a stopgap measure was needed. Prospective investors in the power sector required a level of comfort that ensured that generated power would be bought and paid for promptly. In order to give comfort to these investors, the Nigerian Bulk Electricity Trading Company (NBET), a fully government owned entity, was created, issued an elec- 
tricity trading license and capitalized. NBET's major role was to negotiate Power Purchase Agreements and purchase electricity on behalf of the distribution companies. NBET is therefore a key incentive for the private sector to invest in the power sector as it is mandated to execute bankable Power Purchase Agreements (PPAs) with the private sector. Its capitalization by the government also provided comfort to investors that the institution would be able to meet whatever shortfalls arise from electricity trading in the interim and transitional market periods.

NBET itself is designed as a temporary institution and it is assumed that it would only be required during the interim and transitional periods of the market. In other words, it will be gradually eased out as generation capacity in the country grows, the distribution companies reduce their technical and commercial losses, and the market generally becomes more competitive. Upon the maturing of the market, the PPAs negotiated by NBET will be novated to the distribution companies and NBET wound down. As a prelude to the distribution companies assuming the risk, which NBET currently shoulders, they would be required to post revolving letters of credit that would be called in the event that they fail to meet their obligations.

The true test of the potency of NBET to assume the market risk in the power sector arose immediately after the takeover of the old successor companies by private sector parties. Even though it had been anticipated that there would be a major shortfall in the revenue collection of the distribution companies, the extent of the shortfall was much more than projected. It became quickly apparent that the realised revenues were not enough to settle the debts that had accrued from the power that was generated and sold. As the debt to the generation companies mounted, investors in the sector looked to NBET to come forward and settle them but the institution was unable to do so. This non-liquidity in the market persisted until the Central Bank of Nigeria stepped in recently to provide financing that is now being used to settle the accrued debt in the sector.

It appears that since the technical and commercial losses experienced by the distribution companies are still high, new debts will soon accrue and the bulk trader would still be unable to meet these obligations unless it is further capitalized. Indeed, in the long run, distribution companies should be held strictly accountable to meet all their obligations including the rate of reduction of the Aggregate Technical and Commercial Losses as agreed in their post-acquisition plans. This will improve liquidity in the Nigerian power sector and give confidence to investors.

\subsection{Contract Design}

The contract design, especially within the PPAs, was also used to mitigate demand risk. Demand risk was dealt with by directly guaranteeing a minimum purchase of available power and also indirectly through periodically adjusting tariff and at the occurrence of certain conditions. Despite the availability of these 
terms in the contract, the government has, in practice, been wary of sanctioning any type of tariff increase. The argument by the government is that the user public are likely to protest any increase without any concomitant improvement in power supply. However, this stance is killing the business of the private sector investors and has led to an unreasonable accumulation of debt that is now threatening to destroy the nascent electric power sector in Nigeria. In the event that the government continues to resist the increase in tariff to cost-reflective levels, the only other viable option open to the government is to continue to subsidize the sector. However, even this is not sustainable in the long-term and a long-term solution needs to be found.

\subsection{Multi-Year Tariff Order (MYTO)}

The Multi-Year Tariff Order (MYTO) is essentially a tariff model that seeks to provide a fair cost reflective tariff for the electric power sector in Nigeria. It attempts to achieve this through a transparent mechanism, which adjusts tariffs periodically in relation to inflation, cost of fuel and even foreign exchange fluctuations amongst other variables. Under MYTO the wholesale tariff to be paid to generation companies is pegged at a level estimated to cover the life cycle costs of new entrants into the market. However, it is apparent that MYTO works better with brown field assets like the power plants that were privatized by government and that greenfield plants which are site specific would require a slightly amended methodology. It is in response to this that Nigerian Electricity Regulatory Commission (NERC) allows special tariff rates for individual companies building greenfield power generation plants. For example, the recently negotiated Greenfield Azura Power Plant was granted special tariff rates by the government.

Whilst MYTO has provided a level of certainty and confidence for investors, its review process has recently been tested with limited success. Lately, the Naira dropped massively against the United States Dollar and other currencies impacting negatively on the profits of the investors in the sector since most of the debt borrowed for the purchase of the assets was denominated in Dollars. However, it took several months before the value of the Naira tariffs was adjusted to address this reality. The delay in adjusting tariffs ensures that the private sector would have already suffered considerable losses, as the reviews are never sufficiently made retroactive.

\section{Change of Law Risk}

The change in law risk was basically allocated to the public sector using different scenarios. For example, most of the project documents provided that, if a significant change in law prevents the private sector party from fulfilling its obligations, then the private sector party should be entitled to receive corresponding payments irrespective of its inability to supply contracted services. The private sector can be restored to the same economic position if the change in law results 
in additional cost to the private sector company over and above an agreed threshold. It is important to note that the change in law applied to any change in law after contract negotiation and signing date but did not include changes in tax regulations. One of the key strategies utilized in managing the change of law risk in the electric power sector privatisation was through the use of stabilization clauses.

\section{Stabilization Clauses}

Stabilization clauses are some of the key instruments used to manage change of law risk in projects. Stabilization clauses are risk management devises used to stabilize the expectations of investors; for instance, preventing changes in the laws from adversely affecting the investment contract during the term of the investment. Depending on the party, stabilization clauses are either an absolute necessity or outright dubious. For foreign investors, it protects them from sovereign risks like nationalisation, expropriation or obsolesce bargain.

There were different types of stabilization clauses that were negotiated during the sale of the power assets. This may be broadly categorized into three groups: freezing clauses, consistency clauses, and economic equilibrium clauses. Freezing clauses "freeze" (or restrict) the laws of the host countries by ensuring that the domestic law applicable to the contract is the one in force at the time the contract is concluded to the exclusion of subsequent legislations. Consistency Clauses stipulate that only the domestic legislation of the host state that is consistent with the investment contract, should apply to the project. Therefore, a new legislation will only be applicable to the project if it would not adversely affect the contract. Finally, Economic Equilibrium Clauses permit regulatory changes as long as any adverse effects are negated, by taking action to restore the economic equilibrium of the project. These clauses link alterations of the terms of the contract to a re-negotiation of the contract in order to restore its economic equilibrium or in the absence, to the payment of compensation. The government mostly preferred the economic equilibrium clauses during the power sector privatisation negotiation process.

Stabilization clauses have been criticised for making the public the guarantor or insurer of the private contractors' expected revenues and also clothing private contractors with quasi-government status with powers to influence new laws, judicial decisions and other government actions [31] [32].

Thus, it is feared that these clauses might unwittingly delegate government's constitutional powers to the private sector. The good news is that in most cases the government was able to negotiate out of these clauses.

\section{Exchange Rate Risk}

The government under the contract assumed the foreign exchange risk through the Power Purchase Agreement signed between the government and the private sector. Whilst revenues from power sales were in Naira, tariff was indexed to the 
United States dollar. This was an acknowledgment of the fact that most of the component parts for the maintenance of the power plants are imported using foreign currencies and therefore it was important to ensure that operators were able to maintain the assets on an ongoing basis.

This policy has not functioned well in practice as government has not summoned the political courage to assent to any increase in electricity tariffs. The issue became obvious when the fall in oil prices ensured that the Naira plummeted against the dollar. The revenues accruing to the private sector operators therefore dropped considerably, however NERC found it extremely difficult to adjust tariff to make up the shortfall.

\section{Force Majeure Risk}

The different contracts provided for the management of force majeure risk. At the occurrence of a force majeure event, either party was allowed to terminate the agreement and the project company's obligations under the agreement will cease and the government will pay compensation to the private sector consortium. Upon the payment of the compensation, the consortium was obliged to transfer the asset to the government, lenders will be repaid, and sponsors will receive compensation corresponding to their equity investment. This is in consonance with good project practice and typically what happens in Independent Power Projects. The reason for this is that the private sector party having made significant investments in the asset are unable to uproot and leave the project with the already sunk power assets at the occurrence of a force majeure event. The government is therefore obliged to pay for and take over the asset.

It is also important to stipulate clearly in the contract the events that will amount to force majeure. The creative use of force majeure provisions in contracts may also contribute to the mitigation of political risk. For instance, certain political events like strikes by sector unions may be categorised as a force majeure event, the occurrence of which will bring the contractual relationship between the parties to an end and compel the host government to pay the private sector partner compensation. The private sector requested that widely drawn force majeure clauses be inserted into the negotiated power purchase agreements.

\section{Conclusions}

Under the power sector privatisation programme, Nigeria improved on the management of project risks. There was a significant departure from the erstwhile method of transferring the majority of the risks to private sector operators with very scant attention paid to the mitigation of these risks. However, despite these improvements, the country still has a long way to go in dealing with project risks when engaging the private sector whether during privatisations or PPPs.

The number and level of risk mitigation instruments that were afforded private sector investors by the government under the power sector reforms initially seemed to be adequate incentives for the private sector as evidenced by the high 
number of investors that participated in the different privatisation exercises. However, it is suspected that the high participation in the procurement process, which was driven by the promises of incentives at the beginning of the reforms, will not be replicated in subsequent exercises due to the inconsistencies in the manner these incentives/mitigation instruments were implemented in practice. Of greater worry is the fact that in some cases, government simply failed to honour its promises, and this is bound to have negative consequences as the government tries to consolidate the reforms. The signs are already obvious, as the completed transactions have not necessarily served as catalysts for a further wave of investments in the sector as earlier thought. Also, most of the new investors have not found it easy to raise additional funds for capital expenditure and maintenance of the plants. The present situation is obviously not good for the sustainability of the reforms.

The different risk mitigation instruments were also mostly incorporated into the reform programme through negotiations between the private sector and the government. This method is haphazard in nature and leads to manifest inconsistency in the application. There is therefore now a need for a more standardized framework that takes into consideration all that the government has learnt so far from the reform exercise. Recent negotiations between the government and new investors have still not revealed any semblance of structure. The risk mitigation instruments that are offered are still basically left to the discretion of government officials and the negotiation skills of the private sector. This unfortunately does not lead to consistency of enforcement and may result in the development of an unfair competitive landscape amongst the different private sector players in the sector. There is a need to ensure the uniform applicability of the incentives/instruments across all transactions and investors.

Finally, it has been suggested by some stakeholder groups that the Nigerian government was extremely generous in the offering of the wide spectrum of incentives and risk mitigating instruments discussed above. However, it must be pointed out that this was the price at which investors were willing to acquire the assets at the time due to their perception of risks within the country at the time. It didn't also help that this was the first privatisation exercise in the electric power sector in Nigeria. Therefore, it is understandable that the government needed to be extremely "generous" in the use of the different incentive mechanisms discussed above. It is expected that as the government continues to negotiate more deals and shows fidelity to its obligations under the different agreements that it signed with the investors; it will not require these levels of guarantees as the perception of the country's risks would naturally decline. The government may then gradually scale back on the quantity and level of risk mitigating instruments it provides as incentives.

\section{Conflicts of Interest}

The author declares no conflicts of interest regarding the publication of this paper. 


\section{References}

[1] Bureau of Public Enterprises (2021) Completed Transactions. https://bpe.gov.ng/category/transactions/completed-transactions/

[2] Salako, H.A. (1999) An Overview of Privatisation in Nigeria and Opportunities for its Efficient Implementation. CBN Economic and Financial Review, 37, 17-30.

[3] Nwangwu, G. (2013) A Risk Based Approach to Enhancing Public Private Partnership Projects in Nigeria., Ph.D. Thesis, University of Hull, UK.

[4] Department of economic Affairs (2006) National Public Private Partnership Handbook. Department of Economic Affairs, Ministry of Finance, Government of India, $246 \mathrm{p}$.

[5] Wideman, R. (1992) Project and Program Risk Management PMI.

[6] Akintoye, A.S. and Macleod, M.J. (1997) Risk Analysis and Management in Construction. International Journal of project Management, 15, 31-38. https://doi.org/10.1016/S0263-7863(96)00035-X

[7] Iyer, K.C. and Sagheer, M. (2016) Risk and Uncertainty Assessment in PPP infrastructure Projects: Need for Systems Dynamic Framework.

http://www.indianjournals.com/glogift2k6/glogift2k6-1-1/theme_5/Article\%2011.htm

[8] Al-Bahar, J.F. (1989) Risk Management in Construction Projects: A Systemic Analytical Approach for Contractors. Ph.D. Thesis, University of California Berkeley, USA.

[9] Grimsey, D. and Lewis, K. (2007) Public Private Partnerships: The Worldwide Revolution in Infrastructure Provision and Project Finance. Edward Elgar Publishing, Cheltenham, UK.

[10] Stephen, G. (2005) Practical Risk Assessment for Project Management. John Wiley \& Sons, England.

[11] Taroun, A. (2014) Towards a Better Modelling and Assessment of Construction Risk: Insights from a Literature Review. International Journal of Project Management, 32, 101-115. https://doi.org/10.1016/j.ijproman.2013.03.004

[12] Pellegrino, R., et al. (2013) Real Option Theory for Risk Mitigation in Transport PPPs. Built Environment Project and Asset Management, 3, 199-213. https://doi.org/10.1108/BEPAM-05-2012-0027

[13] Zou, P.X.W. (2008) A life-cycle Risk Management Framework for PPP Infrastructure Projects. Journal of Financial Management and Property Construction, 13, 123-144. https://doi.org/10.1108/13664380810898131

[14] Fischer, K., et al. (2010) An Integrated Risk Management System (IRMS) for PPP Projects. Journal of Financial Management of Property Construction, 15, 260-282. https://doi.org/10.1108/13664381011087515

[15] Xiong, W. (2017) Ex Post Risk Management in Publi-Private Partnerships Infrastructure Projects. Project Mangement Journal, 48, 76-89. https://doi.org/10.1177/875697281704800305

[16] Yin, R.K. (1989) Case Study Research: Design and Methods. Sage Publications, Newbury Park, CA, 22 p.

[17] Yin, R.K. (2003) Case Study Research: Design and Methods. 3rd Edition, Sage Publications, Inc., Thousand Oaks, CA.

[18] Anderson, G. (1993) Fundamentals of Educational Research. Falmer Press, London, 152-160. 
[19] Patton, M. (1987) How to Use Qualitative Methods in Evaluation. Sage Publications, California, 18-20.

[20] Feagin, J., et al. (1991). A Case for Case Study. University of North Carolina Press, Chapel Hill, NC.

[21] Stake, R.E. (1978) The Case Study Method in Social in Social Inquiry. Educational Researcher, 7, 5-8.

[22] Wagner, D. (2000) Defining Political Risk. http://www.irmi.com

[23] Hill, C.A. (1998) How Investors React to Political Risk. Duke Journal of Comparative and International Law, 8, 283-313.

[24] Sachs, T. and Tiong, R.L.K. (2007) The Impact of Political Risk on Public-Private Partnership (PPP) Opportunities in Asia. Civil Engineering Research, 20, 20-23.

[25] United Nations Economic Commission for Europe (2008) Guidebook on Promoting Good Governance in Public-Private Partnerships. United Nations, New York and Geneva.

[26] United Nations Economic and Social Commission for Asia and the Pacific (UNESCAP) Transport Division (2008) Public-Private Partnership in Infrastructure Development. A Primer, Bangkok, 79 p.

[27] Matsukawa, T. and Habeck, O. (2007) Recent Trends in Risk Mitigation Instruments for Infrastructure Finance: Innovations by Providers Opening New Possibilities. Gridlines.

[28] IISD (2021) Investment Law and Policy. International Institute for Sustainable Development. http://www.iisd.org/investment/law/treaties.aspx

[29] Dolzer, R. (2005) The Impact of International Investment Treaties on Domestic Administrative Law. Journal of International Law and Politics, 37, 953-957.

[30] IMF (2006) Public Private Partnerships, Government Guarantees, and Fiscal Risk. International Monetary Fund, Washington DC.

[31] Dannin, E. (2009) Infrastructure Privatisation Contracts and Their Effect on Governance. Legal Studies Research Paper No. 19-2009, The Pennsylvania State University, USA. http://ssrn.com/abstract=1432606

[32] Dannin E. (2011) Crumbling Infrastructure, Crumbling Democracy: Infrastructure Privatisation Contracts and Their Effects on State and Local Governance. Journal of Law and Social Policy, 6, 46-105. 